\title{
ROLE AND IMPORTANCE OF DESTINATION MANAGEMENT COMPANIES IN DEVELOPING CROATIAN TOURIST DESTINATIONS
}

Ivica Batinić,

Vocational school, Vukovar,Croatia ivica.batinic@email.t-com.hr

Professional Paper

doi:10.5937/jouproman6-17222

\begin{abstract}
Specific wishes, needs and demands of modern consumers/tourists, various infrastructural problems and the lack of effective tourist strategies in most Croatian tourist destinations create the need for an effective destination management which will define and come up with effective destination policy for development and improvement of tourism and connect public and private sectors at the destination. Destination management companies which have a highly professional team of tourist experts and managers can influence the tourist industry development at Croatian tourist destinations. Restructuring receptive tourist agencies into destination companies or establishing destination management companies can affect increasing the pleasure of tourists and excursionists, as well as the development of the tourist product of the destination.
\end{abstract}

Keywords: Croatia, destinations, tourist, management, companies, development.

\section{INTRODUCTION}

Most of the problems in Croatian tourist destinations are related to infrastructure and town/city planning (bad roads and traffic regulation at the destination, lack of adequate beach space, poor decorations of parks and promenades, lack of adequate shopping facilities, themed hotels, restaurants and bars...) and the lack of strategic and action plans for tourism development at the destination.

The experiences of many developed world tourist destinations show that wellorganized and responsible destination management can successfully solve or reduce the existing problems and improve the quality of the catering and tourist offer at the destination. In developed world tourist destinations, destination management companies, with a top team of experts and managers, have a very important role in tourist development.

\section{CONCEPTUAL DESIGNATION OF DESTINATION MANAGEMENT COMPANIES}

Every tourist destination, as a supportive and open element of a country's tourism system, must be able to successfully respond to the challenges of the tourist environment and the diverse needs and desires of contemporary consumerstourists. In order for the tourist destination to successfully respond to the needs of the modern tourist market, it is necessary to establish and organize an efficient and responsible destination management with a clearly defined destination tourism policy that will successfully connect all tourist entities with the aim of improving and developing tourism in the destination. 'Destination management must:

- ensure sustainable tourism development and a pleasant environment for the inhabitants 
- ensure that business entities in tourism achieve greater profitability

- utilize the resources of the destination in the best way

- provide the desired quality of tourist experience and outperform market segment expectations

- ensure that long-term benefits from tourism development for the local community are greater than possible damages. '(Avakumović, B., Čorak, S., Magaš, D., Razović, M., Telišman Košuta, N., Trezner . Ž. 2008).

In recent years, in some Croatian tourist destinations, special destination management companies were established with the aim of improving the quality of tourist offer and the long-term development of tourist activity in a tourist destination. What is a destination management company? 'Today, more and more commonly used are simplified definitions that describe a destination management company as a professional service company specializing in the design and organization of tourist events, activities, tours, transfers and logistics programs.' (Marsh, N.2011). 'DMC has a high standard of performance and access to the market based on foreign models, operates within the private sector, takes over part of the function of destination management and also deals with the development and management of specific partial tourism products of the destination.'(Laškarin, M., Galičić, V. 2016). 'Destination management companies are entities that can be partners of tour operators, travel agencies and organizers of gatherings and events, but can also independently act in the organization and sale of complex tourist products - excursions, package deals, events, manifestations, and professional meetings...'(Mitchell, G. 2007). 'Destination management companies often operate on their behalf and offer mostly complex tourist products (excursions, packages, events, gatherings) or their professional design and management services, as opposed to other receptive agencies that operate at the tourist destination on behalf of the client and most often offer simple tourist products and/or mediation services.'(Čorak, S.,Trezner, Ž. 2014).

Based on the aforementioned, it can be concluded that the destination management companies operating in their own name can manage the quality of catering and tourist offer with their tourist activity at the destination in order to develop the destination tourism as a whole.

\section{BASIC SERVICES AND PRODUCTS OF DESTINATION MANAGEMENT COMPANIES}

Destination management company is a tourist entity that acts on its own behalf, knows the local tourism resources, has skilled and professional workers and managers and develops various attractive services and products for a comfortable stay of tourists at the tourist destination. Basic services and products of destination management companies are:

a) Organization of professional conferences and congresses. 'In order to emphasize their ability and specialization to organize professional conferences and congresses, destination management 
companies are also known as Professional Congress Organizers (PCO).' (Schaumann, P. 2005).

b) Organization of various manifestations and events. Because of success in the organization of various tourist events, destination management companies are very often called EMC (Event Management Company).

c) Educational tourism activities. 'The need for discovering new and unknown is increasingly being realized in the form of leisure education. '(Kušen, E. 2002). Tourist activities with educational content (original programs for tourists with special interests) represent a highly specialized tourist product of destination management companies and can be implemented during and outside the tourist season at a tourist destination.

d) Other services. Destination management companies seek to offer primarily their own tourist products and services. However, if they can not make enough income with their own products and services, they can also provide other tourist services, which are mostly of an intermediary nature. 'In the intermediary services we include: mediation in the sale of package tours and excursions, organization, sale and implementation of tourist transfer services, sales, mediation and booking of transportation, sales, mediation and booking of catering services, sales, mediation and reservation of services in special forms of tourist offer...' (Vukonić , B. 1997).

$\begin{array}{lrr}\text { 4.ROLE AND } & \text { IMPORTANCE OF } \\ \text { DESTINATION } & \text { MANAGEMENT } \\ \text { COMPANIES IN } & \text { DEVELOPING } \\ \text { CROATIAN TOURIST DESTINATIONS }\end{array}$

Components of development of destination management in Croatia can be: the public sector (system of tourist boards, local government and self-government), the private sector (business-catering-tourist enterprises) as well as the inhabitants of the tourist destination. For successful destination management, cooperation and co-ordination of the public sector, which provides the basis for the development and promotion of tourist services and products, is extremely important, with the private sector that creates and sells tourism services and products. Tourist boards (public sector) also have a very important role in the development and promotion of tourist destinations. Tourist boards in Croatia must become an effective destination management organization that, in cooperation with other stakeholders in destination management, successfully develop quality and efficient marketing activities with the goal of building a positive "image" and branding of the destination. 'Over and above their traditional functions of destination marketing and in some cases product development, DMOs are increasingly expected to take on more diverse roles within destination governance systems including contributing to and providing leadership to destination stakeholders on aspects of tourism strategy, policy, planning and broader economic, social and environmental changes within the destination. ' (Singh, P. 2014)

Destination management companies can play an important and crucial role in the development of Croatian tourist destinations, because with their expert and professional activities they can influence the improvement of the quality of tourist offer at a tourist destination during and 
outside the tourist season. In some tourist destinations (Pula, Dubrovnik, Zagreb), the establishment of destination management companies or the restructuring of receptive tourist agencies into destination companies has led to an increase in the number and satisfaction of tourists and excursionists and better positioning of destinations on the modern tourist market. Below I mention the tourist activities, organized by the destination management company, which are planned and realized by a professional team of experts and managers of the company.

a) Destination management companies can successfully organize, in cooperation with accommodation facilities, various professional gatherings, congresses or conferences and influence the successful development of congress tourism at the destination. 'Congress tourism is economically very interesting for receptive tourist destinations because the spending of business people, the main congress participants, is usually significantly higher than the spending of standard tourists, and even more balanced during the year.' (Vukonić, B., Čavlek, N. 2001). Every serious and responsible destination management company has a professional team of experts and managers who can successfully organize any smaller or bigger gathering, congress and conference for foreign and domestic guests at the destination. 'Congressional activity is specific and requires a lot of creative work and personal responsibility of the organizer, as it covers a considerably wider area than classic recreational tourism.' (Geić, S. 2011).

b) Destination management companies, as "event" management specialists, have the finest "event" managers capable of organizing various attractive manifestations or events at the destination. 'Managing events presents manager skills and theoretical knowledge which are directly applied to events through elements of organization, providing needed resources, planning and business cooperation.'(Pivčević, S. 2016). 'The most common goals of organizing events are:

- increasing the reputation of the destination,

- getting media attention,

- generating profit,

- extending the tourist season,

- raising public awareness. '( Van Der Wagen, L., Carlos, B. R .2008).

c) Destination management companies can successfully organize various tourist activities with educational contents (geology, botany, ornithology, archeology, ethnography, painting, oenology, gastronomy...), because they have the top lecturers who can meet the specific requirements, needs and wishes of special tourist interest.

d) Destination management companies must have access to top experts (guides) who are capable of meeting the various tourist requirements, whether these are general or themed tours of the tourist destination. Originality of the program of guided tourist tours increases the attractiveness of individual facilities and spaces, and then the tourist destination as a whole.

e) Destination management companies can design top-level team building programs during the stay of tourists at the destination. 'The team building program 
usually focuses on improving group abilities, developing interpersonal relationships, and solving problems that hinder the perfect continuity of work.' (Levi, 2011). A highly professional and expert team can devise a variety of attractive "team building" activities (programs) that will influence the successful development of "team spirit" in the group, make the stay unforgettable and affect the market positioning of the destination as a team building destination.

The aforementioned tourist activities, in the organization of a destination management company as an important destination management company, can provide new or additional income to tourist service providers during or outside the tourist season, to allow tourists and excursionists a pleasant and unforgettable stay at the destination and to influence the successful development of various selective forms of tourism.

\section{CONCLUSION}

In order to become competitive on the demanding tourist market, Croatian tourist destinations have to organize modern destination management which will come up with an effective tourist strategy and successfully connect and include all tourist subjects in the tourist development of the destination.

Establishing various destination management companies, which have to become important participants of the destination management, can affect the improvement of the tourist offer as well as the increase of the number of tourists and excursionists in tourist destinations. Destination management companies, as professional organizators of various expert meetings, conferences, events, tourist activities with educational content and 82 team building activities, can successfully improve quality of the tourist experience at the destination and influence better positioning on the tourist market.

\section{REFERENCES}

1. Avakumović, B., Čorak, S., Magaš, D., Razović, M., Telišman Košuta, N., Trezner, Ž. (2008.) Destinacijske menadžment kompanije-priručnik za razumijevanje poslovanja i uspješan marketing, Zagreb, UHPA

2. Marsh, N. (2011). Best practice in Destination management,Association of destionaition Management Executives.

3. Laškarin, M., Galičić,V. (2016). Prinicipi i praksa turizma i hotelijerstva, Opatija, Fakultet za menadžment u turizmu i ugostiteljstvu

4. Mitchell, G. (2007). Priručnik za tvrtke za upravljanje destinacijom, Zagreb, USAI D

5. Čorak, S., Trezner, Ž. (2014). Destinacijske menadžment kompanije-Ključna pitanja i odgovori za uspješno poslovanje i marketing posebnih interesa, Zagreb, Hrvatska turistička zajednica

6. Schaumann P. (2005). The Guide to Successful Destination Management. Hoboken, New Jersey,John Wiley \& Sons

7. Kušen E. (2002). Turistička atrakcijska osnova. Zagreb, Institut za turizam

8. Vukonić, B. (1997). Turističke agencije, Zagreb, Mikrorad

9. Singh, P. (2014). The role of individuals in the knowledge absorptive capacity of New Zealand's Regional Tourism Organisations. PhD Thesis, Brisbane, The University of Queensland.

10. Vukonić B., Čavlek N. (2001). Rječnik turizma. Zagreb, Masmedia

11. Geić, S. (2011). Menadžment selektivnih oblika turizma, Split, Sveučilište u Splitu

12. Pivčević, S. (2016). Upravljanje manifestacijama, Split, Sveučilište u Splitu 
(JPMNT) Journal of Process Management - New Technologies, International

Vol. 6, No 2, 2018.

13. Van Der Wagen, L., Carlos, B. R. (2008). Event Management - Upravljanje događanjima za turistička, kulturna, poslovna i sportska događanja, Zagreb, MATE

14. Levi, D. (2011). Group dynamics for teams, London, SAGE Publications 